\title{
Review
}

\section{Inflammatory caspases and inflammasomes: master switches of inflammation}

\author{
F Martinon ${ }^{1,2}$ and J Tschopp ${ }^{\star 1}$
}

Fifteen years have passed since the cloning and characterization of the interleukin-1 $\beta$-converting enzyme (ICE/caspase-1), the first identified member of a family of proteases currently known as caspases. Caspase-1 is the prototypical member of a subclass of caspases involved in cytokine maturation termed inflammatory caspases that also include caspase-4 caspase -5 , caspase -11 and caspase -12. Efforts to elucidate the molecular mechanisms involved in the activation of these proteases have uncovered an important role for the NLR family members, NALPs, NAIP and IPAF. These proteins promote the assembly of multiprotein complexes termed inflammasomes, which are required for activation of inflammatory caspases. This article will review some evolutionary aspects, biochemical evidences and genetic studies, underlining the role of inflammasomes and inflammatory caspases in innate immunity against pathogens, autoinflammatory syndromes and in the biology of reproduction. Cell Death and Differentiation (2007) 14, 10-22. doi:10.1038/sj.cdd.4402038; published online 15 September 2006

\section{Inflammatory Caspases}

The history of caspases began with the identification of an aspartate-specific protease activity involved in the conversion of the $31 \mathrm{kDa}$ prolL- $1 \beta$ precursor to its active $17 \mathrm{kDa}$ biologically active form, ${ }^{1,2}$ and the identification of caspase- 1 as the protease responsible for prolL-1 $\beta$ maturation. ${ }^{3,4}$ The subsequent discovery of ced-3, that shares similarities with caspase-1 and which is involved in programmed cell death (PCD) in Caenorhabditis elegans, suggested that caspases might play fundamental roles in apoptosis. ${ }^{5}$ As reviewed in the papers accompanying this issue of Cell Death and Differentiation, the role of apoptotic caspases in $C$. elegans and in vertebrates is crucial and deal with many facets of cell biology, development and diseases. In this review, we will focus on a subset of caspases present only in vertebrates and known as inflammatory caspases.

Inflammatory caspases (also known as group I caspases) are encoded by three main genes in humans caspase-1, caspase- 4 and caspase- 5 and three main genes in mouse, caspase-1, caspase-11 and caspase-12.6,7 In mammals, these caspases are characterized by the presence of a CARD domain at the $\mathrm{N}$-terminus (Figure 1a). Human, chimp and mouse inflammatory caspases share significant similarity and are organized in a single locus (Figure 1c). Phylogenetic analysis of the conserved CARD domain suggests that the inflammatory caspases can be separated in evolutionary- related clusters (Figure 1b). The caspase-1 cluster contains caspase-1 and four other genes encoding decoy caspases: cop, inca1, inca2 and iceberg. These decoy caspase-1-like genes are absent in the mouse genome, suggesting that they have arisen recently by duplication of caspase-1. Although human and mouse caspase-1 are likely orthologues, sequence analysis suggests that human caspase- 4 and caspase- 5 have originated from a duplication of caspase-11. ${ }^{7}$ However, the human caspase-12 gene, which in the chimp genome contains an SHG box important for it enzymatic activity, ${ }^{8}$ evolved towards an enzymatically inactive form at some stage in the recent adaptation process of human species, probably during the out-of Africa migration of modern humans. ${ }^{9,10}$ Initial analysis of the chimp and human genome identified 53 known or predicted genes that are found either entirely or partially deleted in chimpanzee or in human. Intriguingly, those 53 genes include caspase-12 and iceberg, as well as other genes linked with inflammatory caspases such as IL1F7 and IL1F8 (two IL-1-related genes), and NALP12 (see below). ${ }^{8}$ Additional analysis of the inflammatory caspase locus in chimp reveals the absence of cop (Figure 1c), further highlighting the plasticity and rapid and recent evolution of the inflammatory caspase locus.

These caspases are termed 'inflammatory' as the main caspase- 1 substrates identified to date are prolL- $1 \beta$ and prolL18 , two related cytokines that play critical roles in inflammation. A recent report suggests that another IL-1-related

\footnotetext{
${ }^{1}$ Department of Biochemistry, University of Lausanne, BIL Biomedical Research Center, Epalinges, Switzerland

${ }^{*}$ Corresponding author: J Tschopp, Department of Biochemistry, Ch. des Boveresses 155, CH-1066 Epalinges, Switzerland. Tel: + 41-21-692-5738;

Fax: + 41-21-692-5705; E-mail jurg.tschopp@unil.ch

${ }^{2}$ Current address: Department of Immunology and Infectious Diseases, Harvard School of Public Health, 651 Huntington Avenue, Boston, MA 02115, USA

Keywords: inflammasome; NLRs; interleukin- $1 \beta$; sepsis; evolution; innate immunity

Abbreviations: ASC, apoptosis-associated speck-like protein containing a CARD; CARD, caspase recruitment domain; ICE, interleukin-1 $\beta$-converting enzyme; IL-1, interleukin-1; IPAF, ICE protease-activating factor; LRR, leucine-rich repeat; MDP, muramyl dipeptide; MSU, monosodium urate crystals; MyD88, myeloid differentiation protein 88; NACHT, domain present in neuronal apoptosis inhibitory protein (NAIP), the major histocompatibility complex (MHC) class II transactivator (CIITA), HET-E and TP1; NALP, NACHT, LRR and PYD containing proteins; NLR, NOD-like receptors; PAMP, pathogen-associated molecular patterns; PYD, pyrin domain; RI, ribonuclease inhibitor

Received 05.6.06; revised 28.7.06; accepted 31.7.06; Edited by S Kumar; published online 15.9.06
} 
a

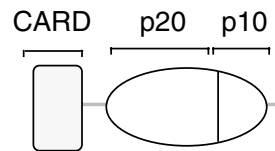

Active Caspases: ex: Caspase-1, 4, 5,11, mouse and chimp Casp-12

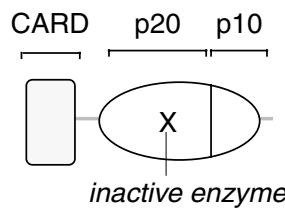

Inactive Caspases: ex: human Caspase-12L

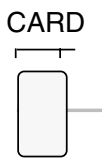

CARD-only

ex: human Caspase-12,

INCA, COP, ICEBERG

b

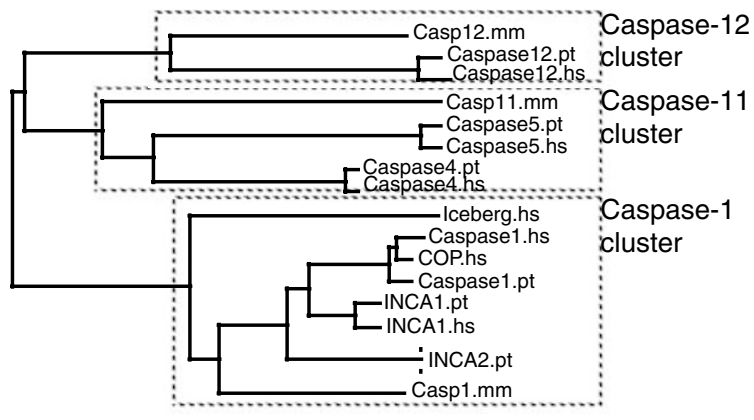

C

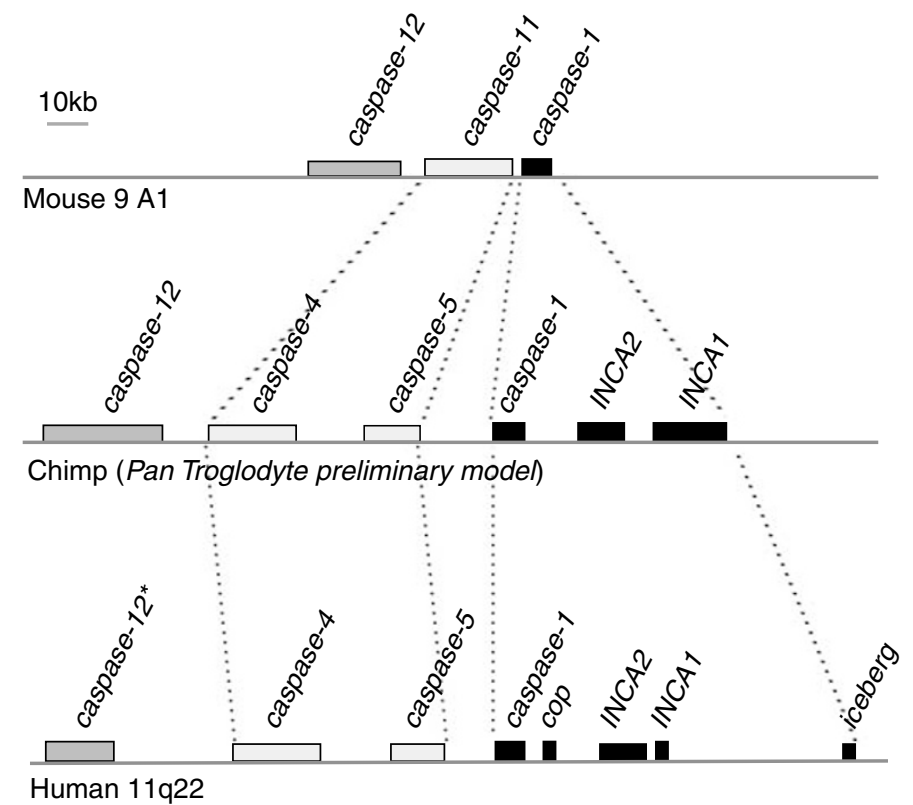

Figure 1 Inflammatory caspases. (a) Schematic domain structure of the inflammatory caspase family. (b) Phylogenic analysis of inflammatory caspases based on the conserved CARD domain from mouse, chimpanzee and human, mm: Mus musculus, hs: Homo sapiens, pt: Pan troglodyte. (c) Organization and evolution of the inflammatory caspase chromosomal locus. Asterisk indicates inactive caspase

cytokine IL-33 is a possible caspase- 1 substrate. ${ }^{11}$ For mouse caspase- 11 and caspase- 12 and human caspase- 4 and caspase- 5 no specific substrates have been identified, therefore the precise function of those caspases is still an open question. Some of the current views on the role of these caspases will be presented in the following sections.

\section{Caspase-1 and it Substrate IL-1 $\beta$}

The requirement of caspase- 1 for IL-1 $\beta$ and IL-18 activities was revealed by the generation of mice deficient in caspase- $1 .{ }^{12-15}$ These mice have a defect in the maturation of prolL- $1 \beta$ and prolL-18 and are resistant to the lethal effect of endotoxins. IL-18 was first described as an endotoxininduced factor that stimulates the production of interferon- $\gamma$ by splenocytes. However, IL-18 has many other functions including induction of pro-inflammatory cytokines, upregulation of adhesion molecules, and activation of natural killer cell activity. ${ }^{16} \mathrm{IL}-1 \beta$ is a major mediator of inflammation and, in general, initiates and/or amplifies a wide variety of effects associated with innate immunity and host responses to microbial invasion and tissue injury. ${ }^{17}$ When mice are immunized with protein antigens together with IL-1 $\beta$, serum antibody production is enhanced, suggesting that IL-1 $\beta$ has adjuvant properties. ${ }^{18}$ On the other hand, the physiological role of IL-1 $\beta$ adjuvanticity and costimulation of $T$ cells has not been fully 
established. Recombinant IL-1 $\beta$ induces fever in experimental animals, an activity shared with other cytokines including tumor necrosis factor (TNF) and IL-6, although the latter cytokines are much less potent than IL-1 $\beta .^{19}$ In addition to fever, IL-1 $\beta$ has other effects on the central nervous system. These include induction of slow-wave sleep, anorexia and inflammatory pain hypersensitivity, typically associated with infections or injury. ${ }^{20,21} \mathrm{IL}-1 \beta$ also influences the function of vessel wall elements, endothelial cells in particular and may contribute to the pathogenesis of arteriosclerosis in different ways, including by promoting coagulation and thrombosis. $^{22,23}$ Importantly, IL-1 $\beta$ was shown to control tumor angiogenesis and invasiveness of different tumor cells in mice. ${ }^{24,25}$ Moreover, IL-1 $\beta$ plays a role in destructive joint and bone diseases. In particular, IL-1 $\beta$ induces production of collagenase by synovial cells and of metalloproteinases by chondrocytes. ${ }^{26}$ Another important characteristic of IL-1 $\beta$ is its toxicity for insulin-producing $\beta$-cells in Langerhans islets, supporting a role of $\mathrm{IL}-1 \beta$ in the pathogenesis of insulin-dependent type I diabetes. ${ }^{27,28}$ Similarly, IL-1 $\beta$ may be toxic for neurons and is involved in acute neurodegeneration and stroke. ${ }^{29}$

Although many important biological effects of $\mathrm{IL}-1 \beta$ are well described, key questions remain unresolved about the mechanism by which the production of this cytokine is regulated. Human prolL-1 $\beta$ must be proteolyticaly cleaved between $\mathrm{Asp}^{116}$ and $\mathrm{Ala}^{117}$ in order to function as an active protein, a process occurring in the cytoplasm. ${ }^{30,31}$ A technical breakthrough in the identification of the mechanisms of prolL$1 \beta$ maturation was the discovery an in vitro assay to monitor prolL- $1 \beta$ maturation. ${ }^{2}$ By this assay, mature IL-1 $\beta$ can be generated by incubation of prolL-1 $\beta$ with partially fractionated extracts from human monocytes or the monocyte-like cell line THP-1. This assay was used to biochemically purify and sequence the IL- $1 \beta$ converting enzyme (ICE) or caspase-1..$^{3,4,32}$ A similar assay allowed the biochemical identification and characterization of the inflammasome, a molecular platform that is spontaneously activated during the hypotonic lysis of THP-1 cells and that triggers caspase-1 activation $^{33}$ (see below). The biological activity of IL-1 $\beta$ is directly associated with caspase- 1 activation and its effects on cytokine maturation. A better understanding of the mechanisms involved in the activation of caspase- 1 is therefore crucial to appreciate the mechanisms of IL-1 $\beta$ regulation.

\section{Mouse Caspase-11 and Human Caspase-4 and Caspase-5}

Murine caspase-11 is a poorly characterized member of the caspase-1 subfamily. Mice deficient in caspase-11 or caspase-1 show a very similar phenotype in response to lipopolysaccharide (LPS) overdose. These mice fail to produce mature $\mathrm{IL}-1 \beta$ and are resistant to endotoxic shock induced by bacterial endotoxins. ${ }^{34}$ Moreover, caspase-11deficient embryonic fibroblasts are resistant to apoptosis induced by ectopic expression of caspase-1, suggesting that caspase-11 is an upstream activator of caspase-1. ${ }^{34}$ Unlike caspase-1, the expression of caspase-11 is LPS-inducible, and it is reasonable to postulate that other members of the family are regulated at the transcriptional or translational level by extracellular stimuli. Based on expression profiles, caspase- 5 was proposed to be the human functional orthologue of caspase-11. ${ }^{35}$ Caspase-5 together with caspase-1 were found to be components of the NALP1 inflammasome, a complex involved in the activation of caspase $-1^{33}$ (see below). These findings reinforced the hypothesis that different inflammatory caspases may cooperate for full activity. Sequence comparison of the caspase domain and prodomains of the inflammatory caspases suggests that both caspase- 4 and caspase- 5 probably arose following the duplication of a caspase-11 ancestor gene. ${ }^{7}$ Little is known about the second possible capase-11 orthologue caspase-4, although a few reports have suggested that caspase- 4 may play a role in endoplasmic reticulum (ER) stress-induced apoptosis, ${ }^{36,37}$ a conclusion challenged by other studies. $^{38}$

\section{Caspase-12: A Role in Sepsis and ER Stress?}

Conditions interfering with the function of ER are collectively called ER stress. ER stress is induced by accumulation of unfolded protein aggregates or by excessive protein trafficking usually owing to viral infection. The ER stress possesses its own signaling pathways that ultimately may result in cell death. Initial studies in caspase-12-deficient mice suggested that this caspase was important for ERstress-induced apoptosis. $^{39}$ In addition, caspase-12 was shown to participate in the development of ER-stress-related neurodegenerative disorders such as Alzheimer's disease or prion associated diseases. ${ }^{39,40}$ Whereas degradation or proteolysis of caspase-12 is a well-established hallmark of ER stress, its central role in ER-stress-induced apoptosis was challenged by various studies. ${ }^{41-43}$ The precise function of caspase-12 in this particular pathway is yet unclear and controversial.

Human polymorphisms of caspase-12 result in the production of either a truncated protein containing the $\mathrm{N}$-terminal CARD domain (CARD-only) or in a full-length variant molecule (Caspase-12L), which was hypothesized to be enzymatically inactive. ${ }^{44}$ The full-length variant of caspase-12 is the less frequent allele, confined to population of African descendant and is linked to hypo-responsiveness to LPS-induced production of cytokines such as IL-1 $\beta .{ }^{44}$ Interestingly, recent genetic studies have suggested that the stop codon generating the CARD-only truncated form of caspase-12 was driven by positive selection to complete fixation in the human genome, approximately 60-100 thousand years ago. ${ }^{9,10}$ This observation suggests that loss of the $\mathrm{C}$-terminus of caspase12 may have conferred a selective advantage, possibly by increasing sepsis resistance in human populations that experienced more and emergent infectious diseases as geographic expansion occurred in association with increasing population size and density. ${ }^{9,10}$ In line with this hypothesis, caspase-12-deficient mice were shown to clear bacterial infection more efficiently than wild-type littermates and have an enhanced production of the pro-inflammatory cytokines IL- $1 \beta$ and IL-18 but not TNF and IL-6. ${ }^{43}$ Mechanistically, caspase-12 was proposed to be a decoy caspase that blocks caspase- 1 activation resulting in enhanced vulnerability to bacterial infection and septic mortality, plausibly in 
the same way as cFLIP (a decoy caspase-8-like protein) regulates caspase-8-mediated apoptosis ${ }^{43}$ (see the accompanying review by Maya Saleh).

\section{Activation of Inflammatory Caspases: Inflammasomes and Other Molecular Machines}

Evolutionarily caspases are linked to the Clan CD of cysteine peptidases that includes legumain, streptopain, separin, metacaspases and paracaspases. ${ }^{45}$ The 'c' in the term 'caspase' is intended to reflect the cysteine protease mechanism and 'aspase' refers to the ability to cleave after aspartic acid, an almost unique preference in eukaryotic enzymes. ${ }^{46}$ All caspases are produced in cells as catalytically inactive zymogens, and generally undergo proteolytic processing during activation. ${ }^{47}$ The subset of caspases that cleaves selected substrates to produce the changes associated with apoptosis are known as 'executioner caspases', which in mammals are represented by caspase- 3 , caspase- 6 and caspase-7. In most instances, executive apoptotic caspases are activated by 'initiator caspases' caspase-8, caspase-10, caspase-2 or caspase-9. The mechanism of activation of these initiator caspases depends critically on the engagement and activation of recruitment platforms such as the deathinducing signaling complex for caspase-8 and caspase-10, the PIDDosome for caspase-2 and the well-described apoptosome, for caspase- $9 .{ }^{48-50}$ These recruitment platforms integrate cellular signals, promote dimerization of initiator caspases and lead to the formation of an active enzyme proficient to initiate specific signaling cascades. ${ }^{51,52}$ These platforms are multiprotein complexes consisting of various molecules assembled on a central scaffold protein that characteristically possesses three main domains: a region involved in ligand sensing, a domain driving oligomerization and a domain involved in recruiting the caspases. The prototypical example is the apoptosome scaffold protein Apaf1. Apaf-1 possesses a CARD for caspase-9 recruitment, a NB-ARC domain for oligomerization and a WD repeat that senses the release of cytochrome $c$ from the mitochondria, a signal that leads to apoptosis by apoptosome activation. A family of intracellular receptors structurally related to Apaf-1 was described in vertebrates recently. These proteins named NOD-like receptors (NLRs) are intracellular sensors of pathogens and other stresses. ${ }^{53,54} \mathrm{NLRs}$ include proteins such as NOD1 and NOD2, that sense bacterial peptidoglycans and activate the kinase RIP2 and nuclear factor $-\kappa \mathrm{B},{ }^{55}$ and three subfamilies of proteins involved in the formation of caspase-1-activating complexes: NALPs, IPAF and NAIPs (Figure 2).

IPAF is a well-conserved protein that contains an $\mathrm{N}$-terminal CARD, a central NACHT domain and a C-terminal leucine-rich repeats (LRR) region. The CARD domain associates directly and specifically with the CARD domain of procaspase-1 through CARD-CARD interactions ${ }^{56}$ (Figure 2).

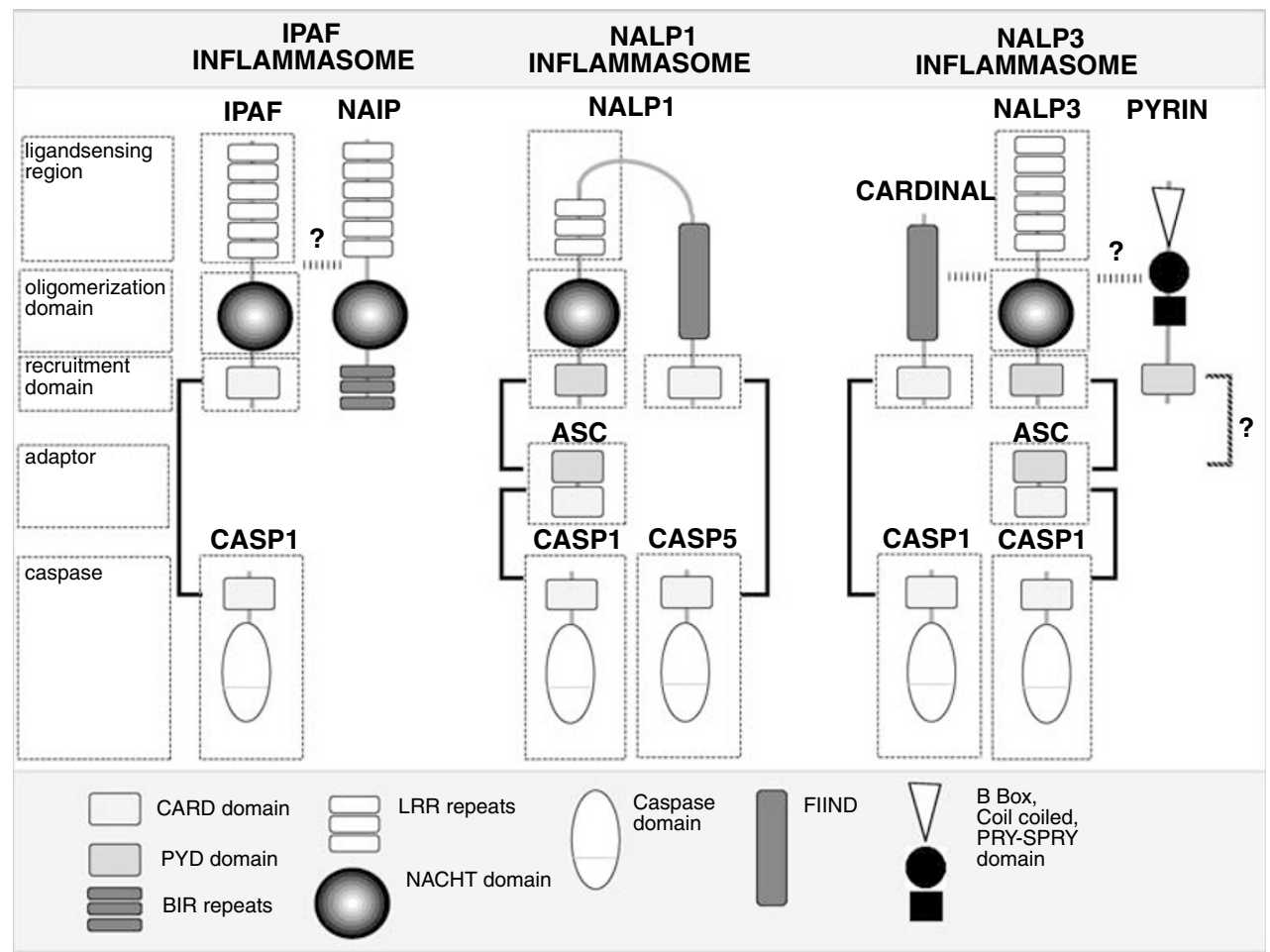

Figure 2 Schematic models of proposed caspase-1-activating inflammasomes. The ligand-sensing motifs (LRR repeats), initiate the formation of oligomers. PYD-PYD and CARD-CARD homotypic interactions are crucial for the recruitment and activation of either the adaptor ASC or the inflammatory caspases. IPAF and NAIP may be part of the same complex, similarly CARDINAL and Pyrin may be involved in the formation or regulation of NALP-based inflammasomes. NALP1 has a C-terminal extension highly similar with CARDINAL. Note that CARDINAL is not present in the mouse genome and mouse NALP1 paralogues have no PYD, it is therefore not clear if those mouse NALP1 paralogues are more related to CARDINAL or human NALP1. Brackets indicate interactions. The boxes identify the various units of the inflammasome, that is, the ligand sensing domain, the oligomerization module, the possible adaptor and the caspase 
Table 1 Human and mouse NALPS, IPAF and NAIP repertoire

\begin{tabular}{|c|c|c|c|c|c|}
\hline \multirow{2}{*}{$\begin{array}{l}\text { NLR } \\
\text { subfamily }\end{array}$} & \multicolumn{2}{|c|}{ Common nomenclature } & \multirow{2}{*}{$\begin{array}{l}\text { Chromosome } \\
\text { localization }\end{array}$} & \multirow[t]{2}{*}{ Other names and aliases } & \multirow[t]{2}{*}{ Structure } \\
\hline & Human & Mouse & & & \\
\hline NALPs & $\begin{array}{l}\text { NALP10 } \\
\text { NALP11 } \\
\text { NALP12 } \\
\text { NALP13 } \\
\text { NALP14 } \\
\text { Ipaf } \\
\text { NAIP }\end{array}$ & $\begin{array}{l}\text { NALP1a } \\
\text { NALP1a } \\
\text { NALP1a } \\
\text { NALP2 } \\
\text { NALP3 } \\
\text { NALP4a } \\
\text { NALP4b } \\
\text { NALP4c } \\
\text { NALP4d } \\
\text { NALP4e } \\
\text { NALP4f } \\
\text { NALP4g } \\
\text { NALP5 } \\
\text { NALP6 }\end{array}$ & $\begin{array}{l}\text { 17p13 } \\
\text { 11B4 } \\
\text { 11B4 } \\
\text { 11B4 } \\
\text { 19q13.42 } \\
\text { 7A1 } \\
\text { 1q44 } \\
\text { 11B1.3 } \\
\text { 19q13.43 } \\
\text { 7A1 } \\
\text { 7A1 } \\
\text { 7A1 } \\
\text { 7A1 } \\
\text { 7A2 } \\
\text { 13B3 } \\
\text { 19q13.42 } \\
\text { 7A2 } \\
\text { 11p15.5 } \\
\text { 7F4 } \\
\text { 19q13.42 } \\
\text { 19q13.42 } \\
\text { 19q13.42 } \\
\text { 7A3 } \\
\text { 7A2 } \\
\text { 7A3 } \\
\text { 11p15.4 } \\
\text { 7E3 } \\
\text { 19q13.42 } \\
\text { 19q13.42 } \\
\text { 7A1 } \\
\text { 19q13.42 } \\
\text { 11p15.4 } \\
\text { 7 E3 } \\
2 \mathrm{p} 22-p 21 \\
\text { 17 E3 } \\
\text { 5q13.1 } \\
\text { 13D1 } \\
\text { 13D1 } \\
\text { 13D1 } \\
\text { 13D1 } \\
\text { 13D1 } \\
\text { 13D1 } \\
\text { 13D1 }\end{array}$ & $\begin{array}{l}\text { DEFCAP; NAC; CARD7 } \\
\\
\text { Pypaf2; NBS1;PAN1 } \\
\text { Pypaf1;CIAS1;Cryopyrin } \\
\text { Cias1, Pypaf1, Mmig1 } \\
\text { Pypaf4;PAN2; RNH2 } \\
\text { Nalp-eta, NALP9D } \\
\text { Nalp-gamma, NALP9E } \\
\text { Nalp-alpha, Rnh2 } \\
\text { Nalp-beta } \\
\text { Nalp-epsilon } \\
\text { Nalp-kappa, NALP9F } \\
\text { Pypaf8; Mater, PAN11 } \\
\text { mater, Op1 } \\
\text { Pypaf5; PAN3 } \\
\text { Pypaf3; NOD12 } \\
\text { PAN4; NOD16 } \\
\text { NOD6 } \\
\text { Nalp-theta } \\
\text { Nalp-delta } \\
\text { Nalp-zeta } \\
\text { PAN5; NOD8; Pynod } \\
\text { Pynod } \\
\text { Pypaf6; NOD17 } \\
\text { Pypaf7; Monarch1; RNO2; PAN6 } \\
\text { NOD14 } \\
\text { NOD5 } \\
\text { Nalp-iota, GC-LRR, } \\
\text { CARD12; CLAN } \\
\text { CARD12; CLAN } \\
\text { BIRC1 } \\
\text { Birc1a, NAIP1 } \\
\text { Birc1b, Naip-rs6, NAIP2 } \\
\text { Birc1c, Naip-rs5, NAIP3 } \\
\text { Birc1d, Naip-rs2, NAIP4 } \\
\text { Birc1e, Naip-rs3, NAIP5 } \\
\text { Birc1f, Naip-rs4, NAIP6 } \\
\text { Birc1g, NAIP7 }\end{array}$ & 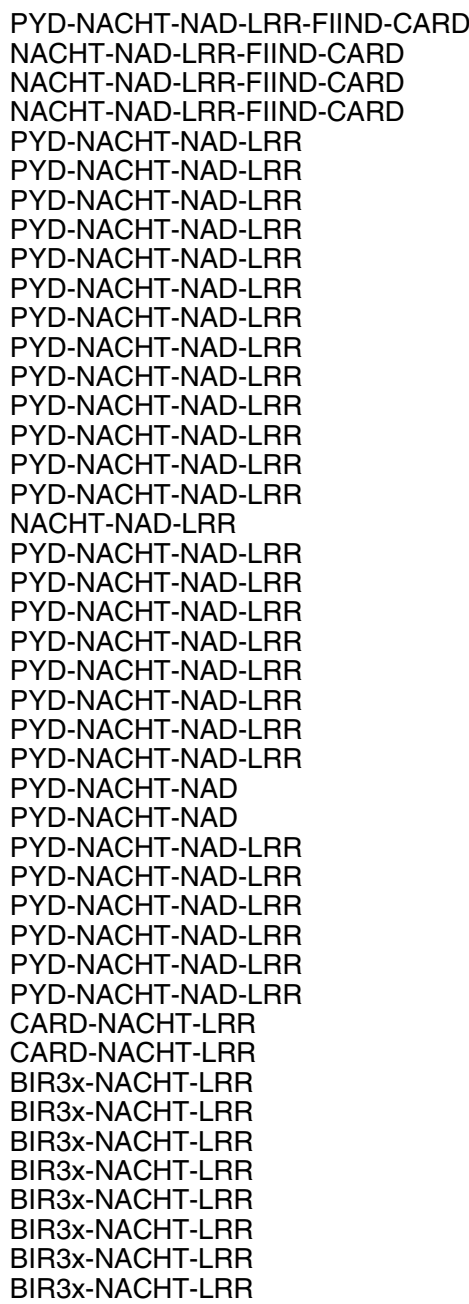 \\
\hline
\end{tabular}

The NACHT domain, related to the NB-ARC domain of Apaf-1, induces oligomerization and promotes proximity of the caspases, whereas the C-terminal LRR is probably involved in ligand sensing. It may also have regulatory properties as its absence leads to the formation of a more active complex. ${ }^{56}$

Despite the absence of a CARD, the neuronal apoptosis inhibitor protein (NAIP) shares with IPAF the highest sequence similarity of the NACHT and LRR domains, suggesting that these molecules are evolutionary and functionally related. ${ }^{57}$ Instead of a CARD, NAIP harbors three $\mathrm{N}$-terminal baculovirus inhibitor-of-apoptosis repeats (BIR), ${ }^{58}$ which were proposed to act as caspase inhibitors. ${ }^{59}$ Mutations in NAIP are associated with the development of spinal muscular atrophy. ${ }^{58}$ Mouse NAIP is mainly expressed in macrophages and is encoded by seven paralogous genes, naip1 to naip7. ${ }^{60}$ NAIP was proposed to interact with IPAF indicating that it may be part of the same caspase-1 activating complex ${ }^{61}$ (Figure 2).
NALPs, represent the largest NLRs subfamily ${ }^{57}$ (Table 1). Some of them such as NALP1, NALP2 and NALP3 were shown to be the central scaffold of caspase-1-activating complexes known as inflammasomes ${ }^{7,33}$ (Figure 2). These proteins harbor an NACHT and an LRR similar to IPAF and NAIP but are characterized by an N-terminal PYD domain. The PYD of NALPS interacts and recruits the adaptor ASC via PYD-PYD interaction. ASC contains an $\mathrm{N}$-terminal PYD and a C-terminal CARD and is an essential component for inflammasome formation. ${ }^{62}$ The CARD domain within ASC binds and recruits caspase- 1 to the inflammasome ${ }^{33,63}$ (Figure 2). The inflammasome may also recruit other caspases such as caspase- 5 via the C-terminal CARD of NALP1 or a second caspase-1 via the C-terminal CARD of CARDINAL, another possible component of the inflammasome. ${ }^{33,64}$

With 14 NALPs, plus Ipaf and NAIP, the repertoire of caspase-1-activating molecular machines is potentially very complex. This complexity can be anticipated to be 
even greater considering some very unusual aspects of the NALP LRRs.

\section{Repertoire and Genomic Organization of the NALP LRRs}

Recognition modules are often organized by repeated motifs. This is the case for example for the cysteine-rich repeats in death receptors, the immunoglobulin domain in IL-1 $\beta$ receptors (IL-1Rs) or WD40 repeats in Apaf-1. Another ligand recognition motif that is frequently found in sensors of pathogens is the LRRs, this domain being found in TLRs and NLRs. These relatively short motifs (22-28 residues in length) can be found in a variety of cytoplasmic, membrane and extracellular proteins. ${ }^{65}$ Although these modules are associated with a wide range of functions, they generally are involved in protein-protein interaction. The LRR structural units consist of a $\beta$ strand and a $\alpha$ helix. The structural units are organized in such a way that all the $\beta$ strands and the helices are parallel to the same axis, resulting in a nonglobular, horseshoe-shaped molecule with the curved $\beta$ parallel sheet lining the inner circumference of the horseshoe and the $\alpha$ helices the outer circumference. ${ }^{65}$

The structures of NALP genes have a highly conserved and intriguing intron-exon organization. Moreover, there is a striking relationship between the intron-exon structure of the NALPs and their modular organization. As illustrated for NALP3 (Figure 3), all the NALPs have one exon that encodes the entire N-terminal PYD, followed by a large exon that code for the NACHT domain, and finally several exons, 171 nucleotides in length that form the LRR. Remarkably, the size, the reading frame phase and the intron-exon junction site are conserved among all NALPs LRRs throughout evolution except for the insertion of an additional amino acid in fugu and zebrafish. Therefore, the LRR within NALPs is defined completely by its intron-exon structure. Why is the NALP LRR exon organization so precise and conserved? The phasing and position of the introns are consistent with rapid and efficient exon amplification during evolution. Moreover, this modular organization allows extensive alternative splicing of the LRR region without disturbing the three-dimensional fold of the region. Alternative splicing of the LRR region is evident for virtually all NALPs as detected by EST analysis and the cloning of various NALPs. ${ }^{66,67}$ Moreover, it is interesting to note that exon-exon junctions disrupt the $\beta$-strand that is predicted in binding targets. Therefore, alternative splicing not only reorganize the numbers of $\beta$ strand but generate completely new $\beta$-strands allowing maximal variability in the ligand recognition region.

The unique other protein sharing exactly the LRR modular organization of the NALPs is the ribonuclease inhibitor, $(\mathrm{RI}) .{ }^{68}$ $\mathrm{RI}$ is able to bind tightly to members of the ribonuclease (RNAse) A superfamily, and is involved in angiogenesis, RNA degradation, cytotoxicity and host-defense responses. ${ }^{69}$ The similarity between NALPs and RI is so close that RI likely represents a decoy form of NALPs. Further studies will be necessary to investigate whether RI interferes with NALP function or has acquired an independent function.

Another feature that characterizes NALPs is their strong tendency to evolve through gene duplication events. Some NALPs such as NALP2 and NALP7 in humans are clearly paralogues, whereas others such as NALP4 and NALP9 are expanded in mouse (Table 1). A similar evolutionary trend was followed by NAIP in mouse where the locus expanded to seven NAIP genes.

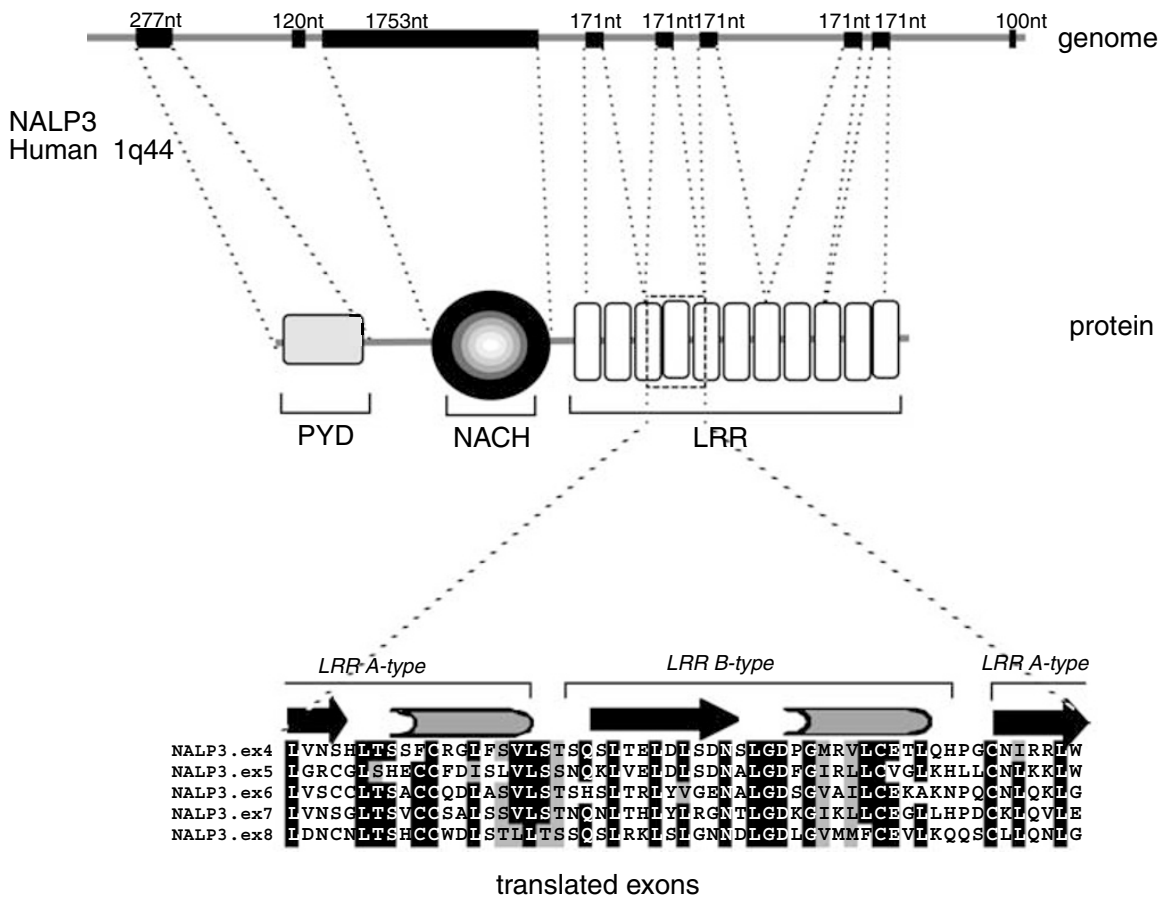

Figure 3 Genomic organization of the NALP3 gene. Note that the 171 nucleotides long (nt) exons that always encode for one LRR plus two-half of two LRRs that are connected by and exon-exon junction within the $\beta$ strand. The reading frame and exon-exon junction are conserved among all the NALPs in all vertebrates. The lower panel shows an alignment of the translated exons forming the NALP3 LRR 
All these observations indicate that the NALP repertoire within a species, and across vertebrates is large and made of different genes and splice variants that mainly differ by their LRR region. Remarkably certain NALPs, such as NALP3, are more conserved. It is therefore tempting to speculate that conserved NALPs are involved in recognition of conserved pathogen-associated molecular patterns or stress signals, whereas rapidly evolving NALPs may be involved in specific host-pathogen interaction, similar to the innate immune system in plants where specific resistance genes (related to the NLRs) detect specific avirulence genes from a pathogen in an host-pathogen, gene for gene, interaction. ${ }^{54,70,71}$ In the presence of a cognate resistance gene, a specific pathogen elicits defense mechanisms and host resistance that lead to a controlled infection. Conversely, in the absence of a specific avirulence gene (of the pathogen) or resistance gene (of the plant), the pathogen eludes specific detection by the host plant, resulting in pathogen proliferation and eventually death of the plant; a bad scenario for both the pathogen and the plant. The challenge for future research is therefore to investigate possible specific interactions between microbial molecular patterns or specific pathogenic factors and various types of inflammasomes. Recent studies have shed some light on some of those interactions (see below).

\section{Toxins and Agents Inducing Potassium Efflux Activate the NALP3 Inflammasome}

The best-studied model of caspase- 1 activation is the exposure of cells to extracellular ATP that activates P2X ion channel receptors. $\mathrm{P} 2 \mathrm{X}_{7}$ receptors belong to a family of ion channel receptors activated by extracellular ATP. ${ }^{72,73}$ Many studies have shown the requirement of $\mathrm{P} 2 \mathrm{X}_{7}$ receptors for ATP-induced caspase- 1 activation and subsequent IL-1 $\beta$ release. ${ }^{74-78}$ However, the physiological relevance of this mechanism, especially in the course of pathogen-induced $\mathrm{IL}-1 \beta$ maturation and release is unclear. $\mathrm{P} 2 \mathrm{X}_{7}$ receptor activation mimics a hypotonic stress situation and requires potassium efflux for caspase- 1 activation, ${ }^{79}$ thus it is possible that the mechanisms, leading to the activation of caspase-1 in the cell-free system and following ATP stimulation, are similar. On the other hand, other models of hypotonic stress and potassium efflux produce comparable caspase- 1 activation. ${ }^{79}$ The generation of ASC (a crucial NALP/caspase-1 adaptor)-deficient mice demonstrated that ATP-mediated caspase-1 activation requires ASC and is therefore probably dependent on the activation of a NALP protein. ${ }^{80}$ This hypothesis was indeed confirmed in studies using NALP3-deficient mice ${ }^{81-83}$ (Figure 4). Another study suggested that NALP3 (also known as cryopyrin) is required for caspase- 1 activation by bacterial RNA or the small antiviral compounds R848 and R837. In this study, caspase-1 activation was monitored in presence of extracellular ATP, and is therefore likely to depend on P2X ${ }_{7}$ activation. ${ }^{84}$ Other agents that decrease intracellular potassium levels such as the potassium ionophore nigericine and maitotoxin, a potent marine toxin, depend on the NALP3-based inflammasome for caspase-1 activation. ${ }^{81}$ NALP3 and ASC are also required for caspase-1 activation by the Gram-positive bacteria Staphylococcus aureus and Listeria monocytogenes. ${ }^{81,85}$ L. monocytogenes-mediated caspase- 1 activation requires the bacterial toxin listeriolysin $O$ (LLO). Whether this toxin and the unidentified caspase-1-activating factor from $S$. aureus are dependent on potassium efflux or NALP3 activation, requires further investigations. ${ }^{81}$

\section{NALP3 Inflammasome and Autoinflammatory Disorders}

Missense mutations in the NACHT domain of NALP3, also known as Cryopyrin or CIAS1 gene, are involved in three autosomal dominant diseases: familial cold auto-inflammatory syndrome, Muckle Wells syndrome and chronic infantile neurological cutaneous and articular syndrome/neonatal onset multisystemic inflammatory disease(CINCA/NOMID). ${ }^{66,86,87}$ All three disorders are closely related autoinflammatory syndromes characterized by periodic fever, skin rashes, amyloidosis and in the case of CINCA, the eventual development of neurological complications. Mutations in NALP3 confer a gain of function to the protein, resulting in constitutively active NALP3 in Muckle Wells patients. ${ }^{64}$ This activation leads to an overactivation of caspase- 1 in monocytes, resulting in an aberrant maturation of IL- $1 \beta$. Treatment of those patients with a natural decoy IL-1 molecule (IL1ra) rapidly and dramatically decreases disease manifestations, ${ }^{88,89}$ further demonstrating that IL-1 $\beta$ is directly responsible for the disease.

The NALP 3 inflammasome and aberrant caspase- 1 activation were recently linked to gout and pseudogout, two other autoinflammatory syndromes. Here, the acute and chronic inflammatory response is associated with the deposition of monosodium urate (MSU) or calcium pyrophosphate dihydrate (CPPD) crystals, respectively, in joints and periarticular tissues. MSU and CPPD stimulate the caspase-1activating NALP3 inflammasome to produce active IL-1 $\beta .^{82}$ Macrophages from mice deficient in various components of the inflammasome such as caspase-1, ASC and NALP3 are defective in crystal-induced IL-1 $\beta$ activation. Moreover, an impaired inflammation is found in an in vivo model of crystal-induced peritonitis in inflammasome-deficient mice or mice deficient in the IL-1R suggesting that in all the above-mentioned autoinflammatory diseases, inflammation is caused by overproduction of IL-1 $\beta{ }^{82}$ Interestingly, IL-18 production is also activated by MSU; ${ }^{82,90}$ nevertheless, IL-18 does not seem to play a crucial role in vivo. ${ }^{90}$

\section{NALP3 and Activation of the Adaptive Immune System}

ASC- and NALP3-deficient mice demonstrate an impaired contact hypersensitivity response to the hapten trinitrophenylchloride (TNP-Cl). ${ }^{83}$ Contact hypersensitivity is a T-cell-mediated immune response to repeated exposure to contact allergens. The response can be divided into two phases: sensitization and elicitation. Caspase-1 and IL-1 $\beta$ have been previously implicated in the sensitization phase. ${ }^{91,92}$ Similarly, NALP3-deficient mice that receive cells from wild-type sensitized animals develop the T-cell dependent elicitor phase, suggesting that NALP3 is involved in the sensitization phase and may bridge the TNP-Cl stress signal 

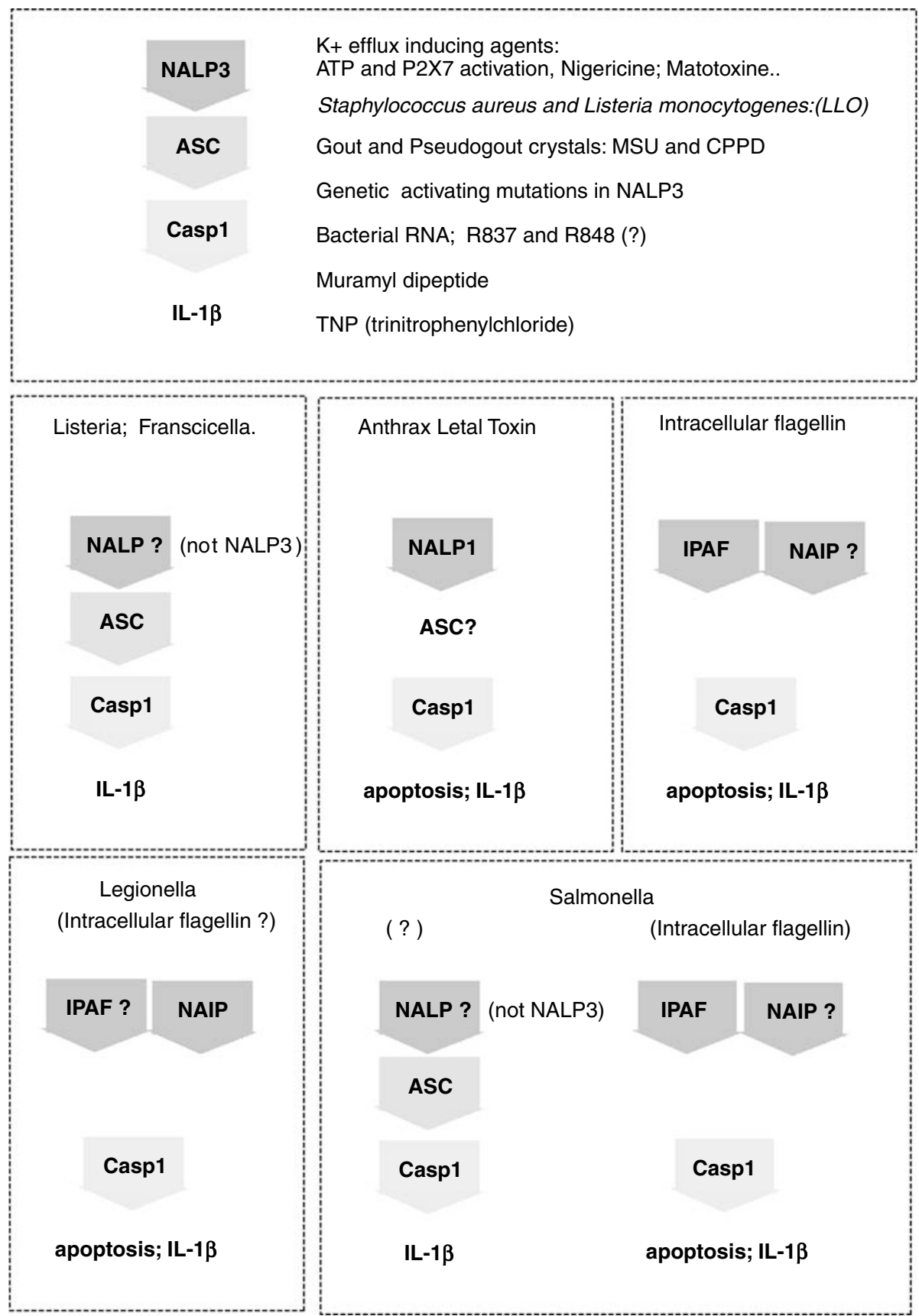

Figure 4 Activation of inflammasomes. Current models of inflammatory caspase activators and their corresponding inflammasome platforms. This figure summarize recent findings mainly revealed by the study of NALP3, ASC and IPAF knockout mice as well as other genetic studies with polymorphisms or mutations in NALP3, NALP1 and NAIP (see the text for details). Note that direct biochemical evidences for most of these inflammasomes are missing

with the activation of the adaptive immunity. A related agent 2,4-dinitrofluorobenzene that is able to induce contact hypersensitivity promotes the release of IL-1 $\beta$ via caspase-1 in a skin dendritic cell line suggesting that the inflammasome may directly detect such compounds. ${ }^{93}$ Furthermore, uric acid crystals and bacterial muramyl dipeptides, two described activators of the NALP3 inflammasome ${ }^{7,82}$ are also well-known adjuvant that are competent in promoting the adaptive immune response. Whether IL-1, which is also an adjuvant per se, or NALP3 inflammasomes are responsible for the adjuvantic properties of these factors remains to be determined in vivo.

\section{ASC Dependent but NALP3 Independent Activation of Caspase-1 by Salmonella and Francisella}

Caspase-1 plays an important role in innate immunity against Salmonella typhimurium, as macrophages and dendritic cells infected with $S$. typhimurium undergo caspase-1-mediated cell death. ${ }^{94,95}$ ASC-deficient macrophages are unable to 
activate caspase-1 following $S$. typhimurium infection. ${ }^{81,83}$ Similarly Francisella tularensis requires ASC to activate caspase-1 and to trigger a competent immune response. ${ }^{96}$ Activation of ASC and caspase-1 by $F$. tularensis is dependent on the internalization and phagosome escape. ${ }^{97}$ NALP3-deficient mice have no apparent defect in caspase-1 activation by $F$. tularensis and $S$. typhimurium. ${ }^{81,83}$ Hence, the NALP involved in ASC-dependent caspase-1 activation by $F$. tularensis and $S$. typhimurium is still unknown (Figure 4).

\section{NALP1 and Susceptibility to Anthrax}

Bacillus anthracis, the causative agent of anthrax, depends for virulence on secretion of factors that form functional toxins such as edema toxin and lethal toxin (LeTx). Edema toxin (consisting of protective antigen (PA) and edema factor) causes the edema associated with cutaneous anthrax infections, whereas LeTx, consisting of PA and lethal factor, is believed to be responsible for causing death in systemic anthrax infections. In mouse macrophages, LeTx can cause rapid apoptosis that requires caspase-1 activation. ${ }^{98}$ Macrophages from inbred mice are either susceptible or resistant to apoptosis by LeTx. This trait difference has been mapped to a locus on chromosome 11 named Ltxs1, and was recently associated with $N A L P 1 b$ gene. ${ }^{99}$ The NALP1 locus in mouse contains three paralogues, $N A L P 1 a, N A L P 1 b$ and NALP1c (Table 1). NALP1b is highly polymorphic in mouse, and susceptibility to LeTx seems to be associated with a functional $N A L P 1 b$ allele and caspase-1 activation. ${ }^{99}$ Murine NALP1b does not contain a PYD; hence, it is not clear whether it requires ASC or dimerization with another NALP for caspase-1 recruitment. However, NALP1b possesses a CARD and a region related to CARDINAL. It is therefore possible that this region per se is able to activate caspase-1 in an ASC-independent manner.

\section{Intracellular Flagellin: Detection by the NLR Proteins NAIP and IPAF}

Part of the capase-1 activation owing to the pathogen Salmonella typhimurium infection was also shown to be IPAF dependent, ${ }^{80}$ but until recently the activating ligand of IPAF was unknown. Two recent studies identified flagellin as the activator for IPAF. They could show that $S$. typhimurium with a deficient flagellin does not stimulate caspase- 1 or IL-1 $\beta$ secretion, and that intracellular flagellin activates an IPAF inflammasome, ${ }^{100,101}$ a mechanism that does not require the other flagellin sensor TLR5. ${ }^{100,101}$ Similarly, other studies showed that NAIP5, a mouse parologue of NAIP, possibly in combination with IPAF, recognizes intracellular flagellin from Legionella pneumophila, in order to induce caspase-1 activation. ${ }^{61,102,103}$ Moreover, early genetic studies in mice clearly identified NAIP5 as a L. pneumophila susceptibility locus, further delineating the importance of inflammatory caspases in the control of bacterial pathogens. ${ }^{104}$

\section{NALPs and the Biology of Reproduction: A Role for the Inflammatory Caspases?}

Intriguingly, the expression profile of some NALPs, together with a few genetic studies, suggest a possible function for these proteins in the biology of reproduction. NALP5 (also known under the name of MATER) displays oocyterestricted basal expression in mouse and human. ${ }^{105,106}$ NALP5-deficient female mice are sterile because of an arrest in the development of the embryos at the two-cell stage. ${ }^{105}$ Other NALPs such as the mouse NALP4 and NALP9 paralogues, NALP4a (also termed NALP9d, see Table 1), NALP4b, NALP4c, NALP4f, NALP9b, NALP9c and bovine NALP5 appear to be expressed exclusively in the ovary whereas mouse NALP9a, NALP14 and bovine NALP9 and NALP8 seem to be essentially expressed both in the ovary and the testis. ${ }^{107-111}$ Interestingly NALP expression levels decrease in the oocyte during maternal aging. ${ }^{110}$ Moreover, knock-down experiments performed in fertilized mouse eggs revealed that a decrease in NALP14 expression leads to embryo failure in mouse compared with control knock-down, mainly owing to an early developmental arrest between the one-cell and eight-cell stages. ${ }^{110}$ The expression of most of those NALPs decreases during the implantation phase, suggesting that NALPs are mainly involved in the early preimplantation phase. Genetic studies also identified allelic variants of NALP5 as possible candidates involved in susceptibility to a mouse model of autoimmune ovarian dysgenesis, an autoimmune disease also characterized by ovary inflammation and the production of autoantibodies against NALP5. ${ }^{112}$ Furthermore, NALP7 mutations cause recurrent hydatidiform mole and reproductive failure in humans. ${ }^{113}$ Hydatidiform mole is an abnormal human pregnancy with no embryo and cystic degeneration of placental villi. Although it is known that inflammation and bacterial infection causes infertility, ectopic pregnancy and abortion, the exact function of NALP7 in this disease remains unidentified. ${ }^{113}$ Similarly, it is unknown whether the developmental failure associated with NALP5 or NALP14 deficiency in the mouse are caused by a deregulated inflammatory caspase activation and consequent overproduction of IL-1 $\beta$ in the ovary. In line with this possibility, IL-1 $\beta$ is known to play a role in both ovulation and oocyte maturation. ${ }^{114}$ For instance in the mare, intrafollicular injection of IL-1 $\beta$ lead to increased ovulation, but also a very low rate of embryo development possibly owing an alteration of ovocyte maturation. ${ }^{115}$ Similarly IL-1 $\beta$ perfusion in the rabbit ovary revealed a block in embryo development at the four-cell stage upon IL-1 $\beta$ stimulation. ${ }^{116}$ It is therefore possible that NALPs and inflammatory caspases may link some aspects of innate immunity and reproductive biology (gamete maturation and early stages of embryo development). This is analogous to the proposed function of Xa13, a resistance gene that play a role both in pollen development and disease resistance in rice, ${ }^{117}$ and for TIP49a, a regulator of the resistance gene RPM1 (a NLR-like resistance gene) that is required for both regulation of resistance and gamete viability in Arabidopsis. ${ }^{118}$

\section{Regulators of Inflammatory Caspase Activation}

Although the production of $\mathrm{IL}-1 \beta$ is critical for the control of pathogenic infections, and for many physiological processes, excessive cytokine production is harmful and needs to be tightly controlled. Regulation of the inflammatory caspases at the inflammasome level is an undoubtedly important 
checkpoint in the control of IL-1 $\beta$ biological activity. Although little is known at the physiological level, various proteins were proposed to interfere with inflammasome assembly and inflammatory caspases activation. Based on their modular structure, we can distinguish two types of inflammasome regulators. The first type is characterized by the presence of a CARD highly similar to the CARD of caspase- 1 . This group includes the decoy caspase-1 genes present in the human caspase-1 locus, such as iceberg, INCA, COP and caspase$12^{7,119-122}$ (Figure 1). Through CARD-CARD interactions these proteins presumably negatively regulate the processing of prolL- $1 \beta$ by preventing direct recruitment and/or activation of the caspase by the adaptor ASC or IPAF. Other inhibitors of the inflammasome are characterized by the presence of a PYD and are believed to interfere with PYD-PYD interactions between ASC and NALPS, blocking therefore specifically the NALP-based inflammasomes. These PYD regulators include Pyrin, POP (DASC) and viral PYDs (vPYDs). POP (a human decoy ASC protein) and the poxviral gene product M13L-PYD (vPYD) are PYD-only protein. ${ }^{7,123,124}$ Viruses deficient in VPYD induce a strong activation of caspase-1 and secretion of $\mathrm{IL}-1 \beta$ indicating that inflammasomes are not only important for antibacterial immunity but also play a role in immunity against viruses. ${ }^{124,125}$

Pyrin was initially identified as the product of the MEFV gene, which is mutated in patients with familial Mediterranean fever (FMF), ${ }^{126}$ a hereditary autoinflammatory syndrome characterized by episodic fever and serosal or synovial inflammation. Targeted disruption of the C-terminal portion of Pyrin in mice causes increased endotoxin sensitivity and caspase-1 activation, ${ }^{127}$ demonstrating the important role of this protein in inflammation and IL-1 $\beta$ maturation. The Pyrin protein is organized with an N-terminal PYD domain followed by an intermediate domain that links the PYD to the TRIM region of Pyrin. The TRIM region is found in a family of proteins with various functions and is characterized by the presence of a B-Box, and a conserved Coiled Coil domain. ${ }^{128}$ The B-Box is often preceded by a RING domain and a Coiled Coil domain, and followed by a PRY and SPRY domains. Pyrin does not contain any RING domain but contains a B-Box, a Coiled Coil and, in humans but not in rat or mice, a PRY and an SPRY domain (Figure 2). Most of the mutations in Pyrin affect the PRY and SPRY domains. ${ }^{129}$ The function of these domains is not clear but a role in the regulation of inflammasome was proposed. ${ }^{127}$ This concept is supported by evolutionary analysis and notably by the presence of this domain as a C-terminal extension (following the LRR) in the NALPs from zebrafish and fugu, and with the identification of new PRY-SPRY containing proteins possibly involved in inflammasome regulation. ${ }^{130,131}$ The PYD of Pyrin was found to interact with the PYD of ASC ${ }^{127}$ suggesting that it may be involved in blocking the recruitment of ASC to the inflammasome. However, another study also proposed a proinflammatory role for Pyrin. In this model, Pyrin, like NALP3, would be able to assemble an inflammasome complex with ASC and procaspase-1 leading to ASC oligomerization, caspase-1 activation and IL-1 $\beta$ processing. ${ }^{132}$ Clearly, the mechanism of action of Pyrin is therefore still controversial. As FMF is an autosomal recessive autoinflammatory disorder it probably requires loss of function of the Pyrin protein. Apparently FMF originated over 2000 years ago in the Middle East and from there it spread to North Africa, Turkey, Armenia, Iraq and the countries on the northern shores of the Mediterranean Sea with the Sephardic expulsion of $1492 .{ }^{126}$ The disease carrier rate in some populations may be extremely high as one in seven. ${ }^{133,134}$ This may reflect a founder effect or some unknown selective pressure, conferring an advantage to the heterozygote carriers. This is possibly the consequence of some environmental or localized infectious diseases that may have affected population around the Mediterranean Sea. Interestingly, the Pyrin mutations in the SPRY and PRY domains often exist as wild-type Pyrin in other primates. ${ }^{135}$ For several of these human mutations, the mutant represents the reappearance of an ancestral amino-acid state and, statistical analysis revealed the presence of episodic positive selection. ${ }^{135}$ Therefore, similarly to what proposed for caspases-12 (another inflammasome regulator, see above and accompanying review by Maya Saleh), selective pressures may have caused functional evolution of pyrin in humans and other primates. PSTPIP1, a Pyrin interacting protein is also mutated in pyogenic arthritis, pyoderma gangrenosum, and acne (PAPA), an autoinflammatory disease associated with overproduction of IL-1 $\beta .{ }^{136}$ Moreover, mutations in a mouse-related protein PSTPIP2 causes a macrophage autoinflammatory syndrome, further delineating the importance of Pyrin and inflammasome regulation in autoinflammatory disorders. ${ }^{137}$

\section{Conclusion}

The regulation and activation of the inflammatory caspases is a very sophisticated and fascinating system to maturate IL-1 $\beta$ and IL-18 that involves many members of the NLRs family of proteins. Both cytokines are activated by inflammasomes and engage specific receptors (IL-1R and IL-18R) that share similarities with the TLRs (a well-known family of innate immune receptors) in the intracellular domain and signaling components such as MyD88. IL-1 can therefore be considered as a cytokine linking intracellular innate immunity receptors to IL-1R/TLR signaling, ${ }^{54}$ a mechanism that seems to evolve rapidly in order to cop as efficiently as possible with specific pathogens.

Although some progress has been made in the characterization of inflammasomes, this is an emerging field and future studies will undoubtedly shed more light on the respective roles of various inflammasomes in human infections and inflammatory diseases and possibly identify new functions for inflammasomes and/or inflammatory caspases.

Acknowledgements. We thank Daniel Muruve, Saskia Lippens, Etienne Meylan, Virginie Pétrilli and Patrizia Vinciguerra for discussions and critical reading of the manuscript. This work was supported by a Swiss National Science Foundation fellowship (FM) and grants of the Swiss National Science Foundation (JT).

1. Black RA, Kronheim SR, Merriam JE, March CJ, Hopp TP. A pre-aspartate-specific protease from human leukocytes that cleaves pro-interleukin-1 beta. J Biol Chem 1989; 264: 5323-5326.

2. Kostura MJ, Tocci MJ, Limjuco G, Chin J, Cameron P, Hillman AG et al. Identification of a monocyte specific pre-interleukin 1 beta convertase activity. Proc Natl Acad Sci USA 1989; 86: 5227-5231. 
3. Cerretti DP, Kozlosky CJ, Mosley B, Nelson N, Van Ness K, Greenstreet TA et al. Molecular cloning of the interleukin-1 beta converting enzyme. Science 1992; 256: 97-100

4. Thornberry NA, Bull HG, Calaycay JR, Chapman KT, Howard AD, Kostura MJ et al. A novel heterodimeric cysteine protease is required for interleukin-1 beta processing in monocytes. Nature 1992; 356: 768-774.

5. Yuan J, Shaham S, Ledoux S, Ellis HM, Horvitz HR. The $C$. elegans cell death gene ced-3 encodes a protein similar to mammalian interleukin-1 beta-converting enzyme. Cell 1993 75: 641-652.

6. Lamkanfi M, Declercq W, Kalai M, Saelens X, Vandenabeele P. Alice in caspase land. A phylogenetic analysis of caspases from worm to man. Cell Death Differ 2002; 9: 358-361.

7. Martinon F, Tschopp J. Inflammatory caspases: linking an intracellular innate immune system to autoinflammatory diseases. Cell 2004; 117: 561-574.

8. Initial sequence of the chimpanzee genome and comparison with the human genome. Nature 2005; 437: 69-87.

9. Wang X, Grus WE, Zhang J. Gene losses during human origins. PLoS Biol 2006; 4: e52.

10. Xue Y, Daly A, Yngvadottir B, Liu M, Coop G, Kim Y et al. Spread of an inactive form of caspase-12 in humans is due to recent positive selection. Am J Hum Genet 2006; 78 : 659-670.

11. Schmitz J, Owyang A, Oldham E, Song Y, Murphy E, McClanahan TK et al. IL-33, an interleukin-1-like cytokine that signals via the IL-1 receptor-related protein ST2 and induces T helper type 2-associated cytokines. Immunity 2005; 23: 479-490.

12. Li P, Allen H, Banerjee S, Franklin S, Herzog L, Johnston $C$ et al. Mice deficient in IL-1 beta-converting enzyme are defective in production of mature IL-1 beta and resistant to endotoxic shock. Cell 1995; 80: 401-411.

13. Kuida K, Lippke JA, Ku G, Harding MW, Livingston DJ, Su MS et al. Altered cytokine export and apoptosis in mice deficient in interleukin-1 beta converting enzyme. Science 1995; 267: 2000-2003

14. Gu Y, Kuida K, Tsutsui H, Ku G, Hsiao K, Fleming MA et al. Activation of interferongamma inducing factor mediated by interleukin-1 beta converting enzyme. Science 1997; 275: 206-209.

15. Ghayur T, Banerjee S, Hugunin M, Butler D, Herzog L, Carter A et al. Caspaseprocesses IFN-gamma-inducing factor and regulates LPS-induced IFN-gamma production. Nature 1997; 386: 619-623.

16. Dinarello CA, Fantuzzi G. Interleukin-18 and host defense against infection. J Infect Dis 2003; 187: S370-384.

17. Dinarello CA. Infection, fever, and exogenous and endogenous pyrogens: some concepts have changed. J Endotoxin Res 2004; 10: 201-222.

18. Staruch MJ, Wood DD. The adjuvanticity of interleukin 1 in vivo. J Immunol 1983; 130 2191-2194.

19. Dinarello CA, Cannon JG, Wolff SM, Bernheim HA, Beutler B, Cerami A et al. Tumor necrosis factor (cachectin) is an endogenous pyrogen and induces production of interleukin 1. J Exp Med 1986; 163: 1433-1450.

20. Krueger JM, Majde JA. Humoral links between sleep and the immune system: research issues. Ann N Y Acad Sci 2003; 992: 9-20.

21. Samad TA, Moore KA, Sapirstein A, Billet S, Allchorne A, Poole S et al. Interleukin-1betamediated induction of Cox-2 in the CNS contributes to inflammatory pain hypersensitivity. Nature 2001; 410: 471-475.

22. Tedgui $A$, Mallat $Z$. Cytokines in atherosclerosis: pathogenic and regulatory pathways. Physiol Rev 2006; 86: 515-581.

23. Libby P. Inflammation in atherosclerosis. Nature 2002; 420: 868-874.

24. Voronov E, Shouval DS, Krelin Y, Cagnano E, Benharroch D, Iwakura $Y$ et al. IL-1 is required for tumor invasiveness and angiogenesis. Proc Natl Acad Sci USA 2003; 100: 2645-2650.

25. Nakao S, Kuwano T, Tsutsumi-Miyahara C, Ueda S, Kimura YN, Hamano S et al Infiltration of COX-2-expressing macrophages is a prerequisite for IL-1 beta-induced neovascularization and tumor growth. J Clin Invest 2005; 115: 2979-2991.

26. Verbruggen $\mathrm{G}$. Chondroprotective drugs in degenerative joint diseases. Rheumatology (Oxford) 2006; 45: 129-138.

27. Sjoholm A. Aspects of the involvement of interleukin-1 and nitric oxide in the pathogenesis of insulin-dependent diabetes mellitus. Cell Death Differ 1998; 5: 461-468.

28. Maedler K, Sergeev P, Ris F, Oberholzer J, Joller-Jemelka HI, Spinas GA et al. Glucoseinduced beta cell production of IL-1beta contributes to glucotoxicity in human pancreatic islets. J Clin Invest 2002; 110: 851-860.

29. Lucas SM, Rothwell NJ, Gibson RM. The role of inflammation in CNS injury and disease. Br J Pharmacol 2006; 147: S232-S240.

30. Hazuda DJ, Lee JC, Young PR. The kinetics of interleukin 1 secretion from activated monocytes. Differences between interleukin 1 alpha and interleukin 1 beta. J Biol Chem 1988; 263: 8473-8479

31. Black RA, Kronheim SR, Cantrell M, Deeley MC, March CJ, Prickett KS et al. Generation of biologically active interleukin- 1 beta by proteolytic cleavage of the inactive precursor. J Biol Chem 1988; 263: 9437-9442.

32. Miller DK, Ayala JM, Egger LA, Raju SM, Yamin TT, Ding GJ et al. Purification and characterization of active human interleukin-1 beta-converting enzyme from THP.1 monocytic cells. J Biol Chem 1993; 268: 18062-18069.

33. Martinon F, Burns K, Tschopp J. The inflammasome: a molecular platform triggering activation of inflammatory caspases and processing of prolL-beta. Mol Cell 2002; 10 417-426.
34. Wang S, Miura M, Jung YK, Zhu H, Li E, Yuan J. Murine caspase-11, an ICE-interacting protease, is essential for the activation of ICE. Cell 1998; 92: 501-509.

35. Lin XY, Choi MS, Porter AG. Expression analysis of the human caspase-1 subfamily reveals specific regulation of the CASP5 gene by lipopolysaccharide and interferongamma. J Biol Chem 2000; 275: 39920-39926.

36. Pelletier N, Casamayor-Palleja M, De Luca K, Mondiere P, Saltel F, Jurdic P et al. The endoplasmic reticulum is a key component of the plasma cell death pathway. $\mathrm{J}$ Immuno 2006; 176: 1340-1347.

37. Hitomi J, Katayama T, Eguchi Y, Kudo T, Taniguchi M, Koyama Y et al. Involvement of caspase-4 in endoplasmic reticulum stress-induced apoptosis and Abeta-induced cell death. J Cell Biol 2004; 165: 347-356.

38. Obeng EA, Boise LH. Caspase-12 and caspase-4 are not required for caspasedependent endoplasmic reticulum stress-induced apoptosis. J Biol Chem 2005; 280 $29578-29587$.

39. Nakagawa T, Zhu H, Morishima N, Li E, Xu J, Yankner BA et al. Caspase-12 mediates endoplasmic-reticulum-specific apoptosis and cytotoxicity by amyloid-beta. Nature 2000 403: 98-103.

40. Hetz C, Russelakis-Carneiro M, Maundrell K, Castilla J, Soto C. Caspase-12 and endoplasmic reticulum stress mediate neurotoxicity of pathological prion protein EMBO J 2003; 22: 5435-5445.

41. Kalai M, Lamkanfi M, Denecker G, Boogmans M, Lippens S, Meeus A et al. Regulation of the expression and processing of caspase-12. J Cell Biol 2003; 162: 457-467.

42. Di Sano F, Ferraro E, Tufi R, Achsel T, Piacentini M, Cecconi F. Endoplasmic reticulum stress induces apoptosis by an apoptosome-dependent but caspase 12-independen mechanism. J Biol Chem 2006; 281: 2693-2700.

43. Saleh M, Mathison JC, Wolinski MK, Bensinger SJ, Fitzgerald P, Droin N et al. Enhanced bacterial clearance and sepsis resistance in caspase-12-deficient mice. Nature 2006 440: 1064-1068.

44. Saleh M, Vaillancourt JP, Graham RK, Huyck M, Srinivasula SM, Alnemri ES et al. Differential modulation of endotoxin responsiveness by human caspase-12 polymorphisms. Nature 2004; 429: 75-79.

45. Barrett AJ, Rawlings ND. Evolutionary lines of cysteine peptidases. Biol Chem 2001; 382 727-733

46. Alnemri ES, Livingston DJ, Nicholson DW, Salvesen G, Thornberry NA, Wong WW et al. Human ICE/CED-3 protease nomenclature. Cell 1996; 87: 171

47. Yan N, Shi Y. Mechanisms of apoptosis through structural biology. Annu Rev Cell Dev Biol 2005; 21: 35-56.

48. Tinel A, Tschopp J. The PIDDosome, a protein complex implicated in activation of caspase-2 in response to genotoxic stress. Science 2004; 304: 843-846.

49. Jiang X, Wang X. Cytochrome C-mediated apoptosis. Annu Rev Biochem 2004; 73: 87-106.

50. Peter ME, Krammer PH. The CD95(APO-1/Fas) DISC and beyond. Cell Death Differ 2003; 10: 26-35.

51. Pop C, Timmer J, Sperandio S, Salvesen GS. The apoptosome activates caspase-9 by dimerization. Mol Cell 2006; 22: 269-275.

52. Boatright KM, Renatus M, Scott FL, Sperandio S, Shin H, Pedersen IM et al. A unified model for apical caspase activation. Mol Cell 2003; 11: 529-541.

53. Werts C, Girardin SE, Philpott DJ. TIR, CARD and PYRIN: three domains for an antimicrobial triad. Cell Death Differ 2006; 13: 798-815.

54. Martinon F, Tschopp J. NLRs join TLRs as innate sensors of pathogens. Trends Immunol 2005; 26: 447-454.

55. Inohara N, Chamaillard M, McDonald C, Nunez G. NOD-LRR proteins: role in hostmicrobial interactions and inflammatory disease. Annu Rev Biochem 2005; 74: 355-383.

56. Poyet JL, Srinivasula SM, Tnani M, Razmara M, Fernandes-Alnemri T, Alnemri ES. Identification of Ipaf, a human caspase-1-activating protein related to Apaf-1. J Biol Chem 2001; 276: 28309-28313

57. Tschopp J, Martinon F, Burns K. NALPs: a novel protein family involved in inflammation Nat Rev Mol Cell Biol 2003; 4: 95-104.

58. Roy N, Mahadevan MS, McLean M, Shutler G, Yaraghi Z, Farahani R et al. The gene for neuronal apoptosis inhibitory protein is partially deleted in individuals with spinal muscula atrophy. Cell 1995; 80: 167-178.

59. Deveraux QL, Leo E, Stennicke HR, Welsh K, Salvesen GS, Reed JC. Cleavage of human inhibitor of apoptosis protein XIAP results in fragments with distinct specificities for caspases. EMBO J 1999; 18: 5242-5251.

60. Endrizzi MG, Hadinoto V, Growney JD, Miller W, Dietrich WF. Genomic sequence analysis of the mouse Naip gene array. Genome Res 2000; 10: 1095-1102.

61. Zamboni DS, Kobayashi KS, Kohlsdorf T, Ogura Y, Long EM, Vance RE et al. The Birc1e cytosolic pattern-recognition receptor contributes to the detection and control of Legionella pneumophila infection. Nat Immunol 2006; 7: 318-325.

62. Yamamoto M, Yaginuma K, Tsutsui H, Sagara J, Guan X, Seki E et al. ASC is essential for LPS-induced activation of procaspase-1 independently of TLR-associated signal adaptor molecules. Genes Cells 2004; 9: 1055-1067.

63. Srinivasula SM, Poyet JL, Razmara M, Datta P, Zhang Z, Alnemri ES. The PYRIN-CARD protein ASC is an activating adaptor for caspase-1. J Biol Chem 2002; 277: 21119-21122.

64. Agostini L, Martinon F, Burns K, McDermott MF, Hawkins PN, Tschopp J. NALP3 form an IL-1beta-processing inflammasome with increased activity in Muckle-Wells autoinflammatory disorder. Immunity 2004; 20: 319-325. 
65. Kobe B, Kajava AV. The leucine-rich repeat as a protein recognition motif. Curr Opin Struct Biol 2001; 11: 725-732.

66. Aganna E, Martinon F, Hawkins PN, Ross JB, Swan DC, Booth DR et al. Association of mutations in the NALP3/CIAS1/PYPAF1 gene with a broad phenotype including recurrent fever, cold sensitivity, sensorineural deafness, and AA amyloidosis. Arthritis Rheum 2002 46: 2445-2452.

67. O'Connor Jr W, Harton JA, Zhu X, Linhoff MW, Ting JP. Cutting edge: CIAS1/cryopyrin/ PYPAF1/NALP3/CATERPILLER 1.1 is an inducible inflammatory mediator with NF-kappa B suppressive properties. J Immunol 2003; 171: 6329-6333.

68. Haigis MC, Haag ES, Raines RT. Evolution of ribonuclease inhibitor by exon duplication. Mol Biol Evol 2002; 19: 959-963.

69. Dickson KA, Haigis MC, Raines RT. Ribonuclease inhibitor: structure and function. Prog Nucleic Acid Res Mol Biol 2005; 80: 349-374.

70. Chisholm ST, Coaker G, Day B, Staskawicz BJ. Host-microbe interactions: shaping the evolution of the plant immune response. Cell 2006; 124: 803-814.

71. Holt III BF, Hubert DA, Dangl JL. Resistance gene signaling in plants - complex similarities to animal innate immunity. Curr Opin Immunol 2003; 15: 20-25.

72. Hogquist KA, Nett MA, Unanue ER, Chaplin DD. Interleukin 1 is processed and released during apoptosis. Proc Natl Acad Sci USA 1991; 88: 8485-8489.

73. Ferrari D, Pizzirani C, Adinolfi E, Lemoli RM, Curti A, Idzko M et al. The P2X7 receptor: a key player in IL-1 processing and release. J Immunol 2006; 176: 3877-3883.

74. Sanz JM, Di Virgilio F. Kinetics and mechanism of ATP-dependent IL-1 beta release from microglial cells. J Immunol 2000; 164: 4893-4898.

75. Perregaux DG, McNiff $P$, Laliberte R, Conklyn M, Gabel CA. ATP acts as an agonist to promote stimulus-induced secretion of IL-1 beta and IL-18 in human blood. J Immunol 2000; 165: 4615-4623.

76. Buell G, Chessell IP, Michel AD, Collo G, Salazzo M, Herren S et al. Blockade of human P2X7 receptor function with a monoclonal antibody. Blood 1998; 92: 3521-3528.

77. Labasi JM, Petrushova N, Donovan C, McCurdy S, Lira P, Payette MM et al. Absence of the $\mathrm{P} 2 \mathrm{X} 7$ receptor alters leukocyte function and attenuates an inflammatory response. $\mathrm{J}$ Immunol 2002; 168: 6436-6445.

78. Solle M, Labasi J, Perregaux DG, Stam E, Petrushova N, Koller BH et al. Altered cytokine production in mice lacking P2X(7) receptors. J Biol Chem 2001; 276: 125-132.

79. Kahlenberg JM, Dubyak GR. Mechanisms of caspase-1 activation by P2X7 receptormediated K+ release. Am J Physiol Cell Physiol 2004; 286: C1100-1108.

80. Mariathasan S, Newton K, Monack DM, Vucic D, French DM, Lee WP et al. Differential activation of the inflammasome by caspase-1 adaptors ASC and Ipaf. Nature 2004; 430 213-218.

81. Mariathasan S, Weiss DS, Newton K, McBride J, O'Rourke K, Roose-Girma M et al. Cryopyrin activates the inflammasome in response to toxins and ATP. Nature 2006; 440 : 228-232.

82. Martinon F, Petrilli V, Mayor A, Tardivel A, Tschopp J. Gout-associated uric acid crystals activate the NALP3 inflammasome. Nature 2006; 440: 237-241.

83. Sutterwala FS, Ogura Y, Szczepanik M, Lara-Tejero M, Lichtenberger GS, Grant EP et al. Critical role for NALP3/CIAS1/Cryopyrin in innate and adaptive immunity through its regulation of caspase-1. Immunity 2006; 24: 317-327.

84. Kanneganti TD, Ozoren N, Body-Malapel M, Amer A, Park JH, Franchi L et al. Bacterial RNA and small antiviral compounds activate caspase-1 through cryopyrin/Nalp3. Nature 2006; 440: 233-236.

85. Ozoren N, Masumoto J, Franchi L, Kanneganti TD, Body-Malapel M, Erturk I et al. Distinct roles of TLR2 and the adaptor ASC in IL-1beta/IL-18 secretion in response to Listeria monocytogenes. J Immunol 2006; 176: 4337-4342.

86. Dode C, Le Du N, Cuisset L, Letourneur F, Berthelot JM, Vaudour G et al. New mutations of CIAS1 that are responsible for Muckle-Wells syndrome and familia cold urticaria: a novel mutation underlies both syndromes. Am J Hum Genet 2002; 70 1498-1506.

87. Hoffman HM, Mueller JL, Broide DH, Wanderer AA, Kolodner RD. Mutation of a new gene encoding a putative pyrin-like protein causes familial cold autoinflammatory syndrome and Muckle-Wells syndrome. Nat Genet 2001; 29: 301-305.

88. Hawkins PN, Lachmann HJ, McDermott MF. Interleukin-1-receptor antagonist in the Muckle-Wells syndrome. N Engl J Med 2003; 348: 2583-2584.

89. Hoffman HM, Rosengren S, Boyle DL, Cho JY, Nayar J, Mueller JL et al. Prevention of cold-associated acute inflammation in familial cold autoinflammatory syndrome by interleukin-1 receptor antagonist. Lancet 2004; 364: 1779-1785.

90. Inokuchi T, Moriwaki Y, Tsutsui H, Yamamoto A, Takahashi S, Tsutsumi Z et al. Plasma interleukin (IL)-18 (interferon-gamma-inducing factor) and other inflammatory cytokines in patients with gouty arthritis and monosodium urate monohydrate crystal-induced secretion of IL-18. Cytokine 2006; 33: 21-27.

91. Antonopoulos C, Cumberbatch M, Dearman RJ, Daniel RJ, Kimber I, Groves RW. Functional caspase- 1 is required for Langerhans cell migration and optimal contact sensitization in mice. J Immunol 2001; 166: 3672-3677.

92. Shornick LP, De Togni P, Mariathasan S, Goellner J, Strauss-Schoenberger J, Karr RW et al. Mice deficient in IL-1beta manifest impaired contact hypersensitivity to trinitrochlorobenzone. J Exp Med 1996; 183: 1427-1436.

93. Matos TJ, Jaleco SP, Goncalo M, Duarte CB, Lopes MC. Release of IL-1beta via IL1 beta-converting enzyme in a skin dendritic cell line exposed to 2,4-dinitrofluorobenzene. Mediators Inflamm 2005; 2005: 131-138.
94. van der Velden AW, Velasquez M, Starnbach MN. Salmonella rapidly kill dendritic cells via a caspase-1-dependent mechanism. J Immunol 2003; 171: 6742-6749.

95. Jarvelainen HA, Galmiche A, Zychlinsky A. Caspase-1 activation by Salmonella. Trends Cell Biol 2003; 13: 204-209.

96. Mariathasan S, Weiss DS, Dixit VM, Monack DM. Innate immunity against Francisella tularensis is dependent on the ASC/caspase-1 axis. J Exp Med 2005; 202 : 1043-1049.

97. Gavrilin MA, Bouakl IJ, Knatz NL, Duncan MD, Hall MW, Gunn JS et al. Internalization and phagosome escape required for Francisella to induce human monocyte IL-1beta processing and release. Proc Natl Acad Sci USA 2006; 103: 141-146.

98. Cordoba-Rodriguez R, Fang $\mathrm{H}$, Lankford CS, Frucht DM. Anthrax lethal toxin rapidly activates caspase-1/ICE and induces extracellular release of interleukin (IL)-1beta and IL18. J Biol Chem 2004; 279: 20563-20566.

99. Boyden ED, Dietrich WF. Nalp1b controls mouse macrophage susceptibility to anthrax lethal toxin. Nat Genet 2006; 38: 240-244.

100. Franchi L, Amer A, Body-Malapel M, Kanneganti TD, Ozoren N, Jagirdar R et al. Cytosolic flagellin requires Ipaf for activation of caspase-1 and interleukin 1beta in salmonellainfected macrophages. Nat Immunol 2006; 7: 576-582.

101. Miao EA, Alpuche-Aranda CM, Dors M, Clark AE, Bader MW, Miller SI et al. Cytoplasmic flagellin activates caspase-1 and secretion of interleukin 1beta via Ipaf. Nat Immunol 2006; 7: 569-575.

102. Molofsky AB, Byrne BG, Whitfield NN, Madigan CA, Fuse ET, Tateda K et al. Cytosolic recognition of flagellin by mouse macrophages restricts Legionella pneumophila infection. $J$ Exp Med 2006; 203: 1093-1104

103. Ren T, Zamboni DS, Roy CR, Dietrich WF, Vance RE. Flagellin-deficient Legionella mutants evade caspase-1- and Naip5-mediated macrophage immunity. PLoS Pathol 2006; 2: e18.

104. Fortier A, Diez E, Gros P. Naip5/Birc1e and susceptibility to Legionella pneumophila. Trends Microbiol 2005; 13: 328-335.

105. Tong ZB, Gold L, Pfeifer KE, Dorward H, Lee E, Bondy CA et al. Mater, a maternal effect gene required for early embryonic development in mice. Nat Genet 2000; 26: 267-268.

106. Tong ZB, Bondy CA, Zhou J, Nelson LM. A human homologue of mouse Mater, a maternal effect gene essential for early embryonic development. Hum Reprod 2002; 17 : 903-911.

107. Dade S, Callebaut I, Paillisson A, Bontoux M, Dalbies-Tran R, Monget P. In silico identification and structural features of six new genes similar to MATER specifically expressed in the oocyte. Biochem Biophys Res Commun 2004; 324: 547-553.

108. Dalbies-Tran $R$, Papillier $P$, Pennetier $S$, Uzbekova $S$, Monget $P$. Bovine mater-like NALP9 is an oocyte marker gene. Mol Reprod Dev 2005; 71: 414-421.

109. Ponsuksili S, Brunner RM, Goldammer T, Kuhn C, Walz C, Chomdej S et al. Bovine NALP5, NALP8, and NALP9 genes: assignment to a QTL region and the expression in adult tissues, oocytes, and preimplantation embryos. Biol Reprod 2006; 74: 577-584.

110. Hamatani T, Falco G, Carter MG, Akutsu H, Stagg CA, Sharov AA et al. Age-a ssociated alteration of gene expression patterns in mouse oocytes. Hum Mol Genet 2004; 13: 2263-2278.

111. Horikawa M, Kirkman NJ, Mayo KE, Mulders SM, Zhou J, Bondy CA et al. The mouse germ-cell-specific leucine-rich repeat protein NALP14: a member of the NACHT nucleoside triphosphatase family. Biol Reprod 2005; 72: 879-889.

112. Roper RJ, Ma RZ, Biggins JE, Butterfield RJ, Michael SD, Tung KS et al. Interacting quantitative trait loci control loss of peripheral tolerance and susceptibility to autoimmune ovarian dysgenesis after day 3 thymectomy in mice. J Immunol 2002; 169: $1640-1646$

113. Murdoch S, Djuric U, Mazhar B, Seoud M, Khan R, Kuick R et al. Mutations in NALP7 cause recurrent hydatidiform moles and reproductive wastage in humans. Nat Genet 2006; 38: 300-302.

114. Gerard N, Caillaud M, Martoriati A, Goudet G, Lalmanach AC. The interleukin-1 system and female reproduction. $J$ Endocrinol 2004; 180: 203-212.

115. Caillaud M, Duchamp G, Gerard N. In vivo effect of interleukin-1beta and interleukin-1RA on oocyte cytoplasmic maturation, ovulation, and early embryonic development in the mare. Reprod Biol Endocrinol 2005; 22: 3:26

116. Takehara Y, Dharmarajan AM, Kaufman G, Wallach EE. Effect of interleukin-1 beta on ovulation in the in vitro perfused rabbit ovary. Endocrinology 1994; 134: 1788-1793.

117. Chu Z, Yuan M, Yao J, Ge X, Yuan B, Xu C et al. Promoter mutations of an essential gene for pollen development result in disease resistance in rice. Genes Dev 2006; 20: $1250-1255$

118. Holt 3rd BF, Boyes DC, Ellerstrom M, Siefers N, Wiig A, Kauffman S et al. An evolutionarily conserved mediator of plant disease resistance gene function is required for normal Arabidopsis development. Dev Cell 2002; 2: 807-817.

119. Humke EW, Shriver SK, Starovasnik MA, Fairbrother WJ, Dixit VM. ICEBERG: a novel inhibitor of interleukin-1beta generation. Cell 2000; 103: 99-111.

120. Lee SH, Stehlik C, Reed JC. Cop, a caspase recruitment domain-containing protein and inhibitor of caspase-1 activation processing. J Biol Chem 2001; 276: 34495-34500.

121. Druilhe A, Srinivasula SM, Razmara M, Ahmad M, Alnemri ES. Regulation of IL-1beta generation by Pseudo-ICE and ICEBERG, two dominant negative caspase recruitment domain proteins. Cell Death Differ 2001; 8: 649-657. 
122. Lamkanfi M, Denecker G, Kalai M, D'Hondt K, Meeus A, Declercq W et al. INCA, a novel human caspase recruitment domain protein that inhibits interleukin-1beta generation. J Biol Chem 2004; 279: 51729-51738.

123. Stehlik C, Krajewska M, Welsh K, Krajewski S, Godzik A, Reed JC. The PAAD/PYRINonly protein POP1/ASC2 is a modulator of ASC-mediated nuclear-factor-kappa B and pro-caspase-1 regulation. Biochem J 2003; 373 (Part 1): 101-113.

124. Johnston JB, Barrett JW, Nazarian SH, Goodwin M, Ricuttio D, Wang G et al. A poxvirusencoded pyrin domain protein interacts with ASC-1 to inhibit host inflammatory and apoptotic responses to infection. Immunity 2005; 23: 587-598.

125. Benedict CA, Ware CF. Poxviruses aren't stuPYD. Immunity 2005; 23: 553-555.

126. Kastner DL. Familial Mediterranean fever: the genetics of inflammation. Hosp Pract (Minneapolis) 1998; 33: 131-146.

127. Chae JJ, Komarow HD, Cheng J, Wood G, Raben N, Liu PP et al. Targeted disruption of pyrin, the FMF protein, causes heightened sensitivity to endotoxin and a defect in macrophage apoptosis. Mol Cell 2003; 11: 591-604.

128. Reymond A, Meroni G, Fantozzi A, Merla G, Cairo S, Luzi L et al. The tripartite motif family identifies cell compartments. EMBO J 2001; 20: 2140-2151.

129. Ting JP, Kastner DL, Hoffman HM. CATERPILLERs, pyrin and hereditary immunological disorders. Nat Rev Immunol 2006; 6: 183-195.

130. Munding C, Keller M, Niklaus G, Papin S, Tschopp J, Werner S et al. The estrogenresponsive $B$ box protein: a novel enhancer of interleukin-1beta secretion. Cell Death Differ 2006; 31 (in press, doi: 10.1038/sj.cdd.4401896).
131. Grutter C, Briand C, Capitani G, Mittl PR, Papin S, Tschopp J et al. Structure of the PRYSPRY-domain: implications for autoinflammatory diseases. FEBS Lett 2006; 580 99-106.

132. Yu JW, Wu J, Zhang Z, Datta $P$, Ibrahimi I, Taniguchi $S$ et al. Cryopyrin and pyrin activate caspase-1, but not NF-kappaB, via ASC oligomerization. Cell Death Differ 2006 13: 236-249.

133. Stoffman N, Magal N, Shohat T, Lotan R, Koman S, Oron A et al. Higher than expected carrier rates for familial Mediterranean fever in various Jewish ethnic groups. Eur J Hum Genet 2000; 8: 307-310.

134. Aksentijevich I, Torosyan Y, Samuels J, Centola M, Pras E, Chae JJ et al. Mutation and haplotype studies of familial Mediterranean fever reveal new ancestral relationships and evidence for a high carrier frequency with reduced penetrance in the Ashkenazi Jewish population. Am J Hum Genet 1999; 64: 949-962.

135. Schaner P, Richards N, Wadhwa A, Aksentijevich I, Kastner D, Tucker P et al. Episodic evolution of pyrin in primates: human mutations recapitulate ancestral amino acid states. Nat Genet 2001; 27: 318-321.

136. Shoham NG, Centola M, Mansfield E, Hull KM, Wood G, Wise CA et al. Pyrin binds the PSTPIP1/CD2BP1 protein, defining familial Mediterranean fever and PAPA syndrome as disorders in the same pathway. Proc Natl Acad Sci USA 2003; 100: 13501-13506.

137. Grosse J, Chitu V, Marquardt A, Hanke P, Schmittwolf C, Zeitlmann L et al. Mutation of mouse Mayp/Pstpip2 causes a macrophage autoinflammatory disease. Blood 2006; 107 3350-3358 